\title{
The Impact of Problem-Based Workshops on Improving Teacher Competency in Designing Learning Based on Environmental Potential
}

\author{
Fatni Mufit, Desnita, Fandi Oktasendra \\ Jurusan Fisika, Fakultas Matematika dan Ilmu Pengetahuan Alam, Universitas Negeri Padang Jl. Prof. Dr. Hamka Air \\ Tawar, Indonesia \\ *fatni_mufit@fimpa.unp.ac.id; Tel.: +62-813-633-79223
}

Diterima 7 Desember 2019, Disetujui 14 November 2020, Dipublikasikan 30 November 2020

\begin{abstract}
The competence of science teachers in Padang City Junior High Schools in developing learning tools is still low, as revealed by the teacher's pre-test abilities before the workshop is held. Pretest includes gathering information about learning resources, learning media, models / methods / approaches, and assessment instruments used by teachers not yet utilizing the environment. Referring to the problems of teachers, problem-based workshop activities are designed in an effort to improve teacher competencies in designing learning tools based on environmental potential. Problem-based workshops have stages: (1) problem identification, (2) Focusing on problems, (3) Finding alternative solutions, (4) Presentation of solutions; (5) Implementation and (6) Reflection \& follow-up. The workshop was attended by 20 junior high school science teachers in Padang city. The workshop activities consisted of 2 parts, namely the workshop activities at FMIPA UNP and the Implementation activities at SMP 25 Padang. Problem-based workshops succeeded in increasing teacher competence in designing IPA-based environmental learning tools. The results of the implementation of the workshop products by the teacher showed a positive influence on student involvement and activity in learning
\end{abstract}

Keywords — problem-based workshops, designing science learning, environmental potential.

\section{Pendahuluan}

Pendidikan formal tingkat dasar dan menegah di Indonesia saat ini dikelola dan dilaksanakan dengan acuan delapan standar pendidikan. Salah satu standar tersebut adalah Standar Pendidik dan Tenaga Kependidikan. Pendidik atau Guru menurut Peraturan Pemerintah No. 19 tahun 2006 jo Peraturan Pemerintah No. 32 tahun 2013, adalah profesi yang dituntut memiliki empat kompetensi; yaitu Kompetensi Profesional, Kompetensi Pedagogik, Kompetensi Sosial, dan Kompetensi Kepribadian. Salah satu sub kompetensi dari kompetensi pedagogik adalah merancang perangkat pembelajaran yang membelajarkan siswa.

Pembelajaran yang berpusat pada peserta didik merupakan wujud dari upaya guru memenuhi kebutuhan belajar abad 21 yang dikenal dengan 4C; Critical Thinking, Creativity \& Inovation, Collaboration, dan Communication. Salah satu tujuan pembelajaraan adalah agar siswa dapat menyelesaikan masalah dalam kehidupan sehari hari. Kemampuan menyelesaikan masalah sehari hari, hanya dapat dilatih dengan cara memanfaatkan lingkungan sebagai sumber belajar dan media pembelajaran.

Kompetensi guru IPA SMP Kota Padang dalam menyusun perangkat pembelajaran masih rendah, yang terungkap dari perangkat 
pembelajaran yang ditulis guru sebelum workshop (pretest). Hasil pretest menunjukkan kemampuan guru dalam memilih sumber belajar, media pembelajaran, dan model/metode/ pendekatan pembelajaran, serta instrumen penilaian belum optimal, terutama dalam memanfaatkan potensi lingkungan di sekitar siswa. Sumber belajar bagi siswa masih dominan berasal dari guru, dan kurang memanfaatkan lingkungan. Bahan ajar dan media pembelajaran yang digunakan guru kurang bervariasi. Bahan ajar masih berfokus pada buku teks yang ada di sekolah. Pemanfaatan teknologi dalam pembelajaran masih kurang, seperti penggunaan video pembelajaran, terutama yang berbasis potensi lingkungan. Secara umum, rancangan dan pelaksanaan pembelajaran di sekolah belum optimal memanfaatkan teknologi dan belum memanfaatkan lingkungan siswa sebagai sumber belajar dalam penemuan konsep-konsep sains (IPA).

Rendahnya kompetensi guru IPA SMP kota Padang menyusun perangkat pembelajaran berbasis potensi lingkungan berdampak terhadap rendahnya kualitas pembelajaran dan tentunya berdampak tidak baik terhadap tingkat pencapaian kompetensi. Kebutuhan belajar siswa 4C tidak akan terpenuhi, sekaligus kemampuan siswa menyelesaikan masalah sehari hari juga tidak akan tercapai. Permasalahan yang memiliki efek domino ini harus segera diatasi.

Bertitik tolak pada permasalahan yang dialami guru, maka dirancang kegiatan workshop untuk meningkatkan kompetensi guru dalam merancang perangkat pembelajaran berbasis potensi lingkungan. Workshop yang dilakukan berbasis pada masalah guru atau disebut sebagai problem based workshop. Workshop berbasis masalah mengacu pada pembelajaran berbasis masalah (PBL) yang dikemukakan Ronis [1], yang mempunyai 7 tahapan, yaitu: (1) menentukan apakah suatu masalah ada, (2) membuat pernyataan yang tepat dari permasalahan tersebut, (3) mengidentifikasi informasi yang dibutuhkan untuk memahami masalah tersebut, (4) mengidentifikasi sumber-sumber untuk mengumpulkan informasi, (5) membangun solusi yang mungkin, (6) menganalisis solusi, (7) mempresentasikan solusi, secara lisan dan atau tulisan. Tahapan ini selanjutnya diakomodasi sebagai tahapan workshop bagi guru untuk merancang pembelajaran IPA berbasis potensi lingkungan.

Workshop berbasis masalah ini dikemas sesuai dengan pendidikan orang dewasa atau andragogik. Sebagai pribadi, orang dewasa memiliki kemandirian dan mampu mengarahkan diri sendiri, serta memiliki kematangan konsep diri. Selain itu, sebagai pribadi yang mempunyai kematangan psikologi, orang dewasa mampu mengarahkan diri sendiri, bukan diarahkan, dipaksa maupun dimanipulasi oleh orang lain [2]. Orientasi belajar orang dewasa lebih fokus pada masalah dari pada konten [3].

Berbeda dengan pedagogik (pendidikan kanakkanak), pada pembelajaran andragogik, guru sebagai peserta didik terlibat secara aktif dalam menentukan tujuan, menyusun rencana kegiatan, melaksanakan, dan mengevaluasi dampak kegiatan. Pada kegiatan workshop berbasis masalah ini, guru yang menggali sendiri permasalahannya, mencari alternatif solusi, menerapkan solusi, dan mengevaluasi kegiatan. Sehingga dirasakan dampak langsung kegiatan tersebut bagi guru. Penelitian ini bertujuan untuk melihat dampak workshop berbasis masalah terhadap peningkatan kemampuan guru dalam menyusun rancangan pembelajaran IPA SMP berbasis potensi lingkungan

\section{Solusi/Teknologi}

Setelah melakukan diskusi dengan Ketua MGMP IPA SMP Kota Padang, dibuat kesepakatan untuk melaksanakan kegiatan workshop berbasis masalah untuk menyusun perangkat pembelajaran IPA SMP berbasis potensi lingkungan. Berdasarkan tahapan yang dikemukanan Ronis, maka dirancang workshop berbasis masalah dengan langkah sebagai berikut: (1) Identifikasi masalah, yaitu menemukan beberapa masalah yang dihadapi guru dalam pembelajaran, (2) Pemfokusan masalah, yaitu perumusan masalah utama yang dialami guru, (3) Penemuan solusi, yaitu diskusi kelompok oleh guru dalam mencari solusi terbaik dari permasalahan yang dipilih, (4) Presentasi solusi oleh setiap kelompok guru terhadap masalah 
utama yang dipilih, serta diskusi kelas, (5) Implementasi/menerapkan solusi dalam situasi nyata; dan (5) refleksi dan penilaian efektivitas solusi

Sebelum kegiatan workshop, dilakukan pretes untuk mengetahui pengetahuan awal guru dalam merancang pembelajaran. Pretes mencakup kemampuan guru dalam memilih sumber belajar, media pembelajaran, bahan ajar dan instrument penilaian dalam menyusun Rancangan Pelaksanaan Pembelajaran (RPP). Selanjutnya narasumber memaparkan materi tentang bagaimana merancang pembelajaran yang berbasis potensi lingkungan, yang meliputi penyusunan RPP, bahan ajar dan media pembelajaran yang berbasis potensi lingkungan. Narasumber memberikan contoh RPP dan media berupa video pembelajaran yang berbasis potensi lingkungan.

Pelaksanaan workshop dilakukan dengan dua tahapan utama pada dua lokasi, yaitu tahapan workshop yang dilaksanakan di FMIPA UNP dan tahapan implementasi yang dilaksanakan di SMP 25 Padang. Secara umum deskripsi kegiatan pada setiap tahap workshop berbasis masalah dapat dilihat pada Tabel 1.

Table 1. Kegiatan pada Setiap Tahap Workshop Berbasis Masalah

\begin{tabular}{|c|c|}
\hline Tahap & Deskripsi Kegiatan \\
\hline $\begin{array}{l}\text { Identifikasi } \\
\text { masalah }\end{array}$ & $\begin{array}{l}\text { Menemukan sejumlah permasalahan } \\
\text { guru dalam merancang perangkat } \\
\text { pembelajaran IPA berbasis potensi } \\
\text { lingkungan }\end{array}$ \\
\hline $\begin{array}{l}\text { Penfokusan } \\
\text { masalah }\end{array}$ & $\begin{array}{l}\text { Menyusun skala prioritas dan } \\
\text { ditetapkan satu masalah pada masing } \\
\text { masing kelompok, untuk diselesaikan } \\
\text { melalui workshop }\end{array}$ \\
\hline $\begin{array}{l}\text { Mencari } \\
\text { alternatif solusi }\end{array}$ & $\begin{array}{l}\text { Memperoleh alternatif pemecahan } \\
\text { masalah, dan menulis perangkat } \\
\text { pembelajaran yang memanfaatkan } \\
\text { potensi lingkungan. }\end{array}$ \\
\hline Presentasi solusi & $\begin{array}{l}\text { Presentasi draft perangkat } \\
\text { pembelajaran oleh setiap kelompok \& } \\
\text { diskusi kelas menerima masukan. }\end{array}$ \\
\hline Implementasi & $\begin{array}{l}\text { Setiap Kelompok melaksanakan } \\
\text { pembelajaran dalam kelas nyata sesuai } \\
\text { perangkat yang telah disusun. }\end{array}$ \\
\hline $\begin{array}{l}\text { Refleksi \& } \\
\text { Tindak Lanjut }\end{array}$ & $\begin{array}{l}\text { Diskusi kelompok untuk melakukan } \\
\text { refleksi \& tindak lanjut atas } \\
\text { pelaksanaan/implementasi. }\end{array}$ \\
\hline
\end{tabular}

Peserta workshop terdiri dari 20 orang guru yang mewakili 20 SMP di Kota Padang. Peserta workshop dibagi dalam tiga kelompok sesuai tingkatan kelas, yaitu kelompok guru kelas 7, kelas 8 dan kelas 9. Guru peserta workshop diharapkan menjadi pionir di sekolah masingmasing dalam mensosialisasikan manfaat workshop yaitu merancang pembelajaran yang berbasis potensi lingkungan.

Pada tahap 1, yaitu identifikasi masalah, setiap kelompok guru menemukan materi atau Kompetensi Dasar (KD) yang mereka rasakan sulit dalam merancang RPP yang mengaitkan dengan lingkungan sekitar siswa. Pada kelompok kelas 7, kelas 8 dan kelas 9 mereka menemukan dan mendata 3 materi / KD yang sulit. Pada tahap 2, yaitu pemfokusan masalah, setiap kelompok mendiskusikan kembali masalah yang paling prioritas untuk dicarikan solusi. Pada Tabel 2 terlihat masalah yang paling prioritas dalam setiap kelompok.

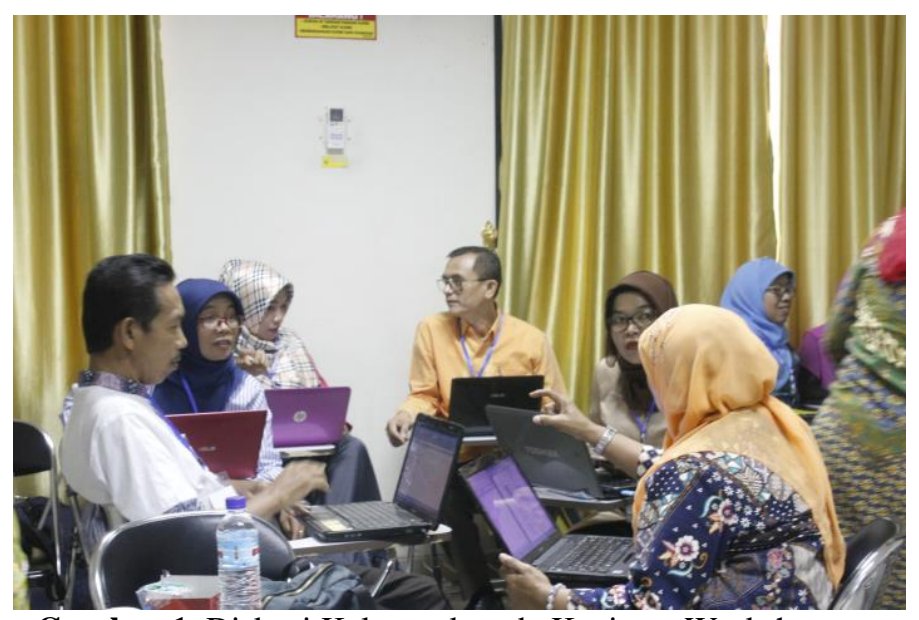

Gambar 1. Diskusi Kelompok pada Kegiatan Workshop Berbasis Masalah

Pada tahap 3, setiap kelompok mendiskusikan solusi dari permasalahan mereka, dengan merancang RPP, bahan ajar dan media yang tepat untuk setiap KD yang mereka rasa sulit. Setiap kelompok peserta mendapat arahan dan bimbingan instruktur tim pengabdian dalam menyusun rancangan pembelajaran tersebut. Pada tahap ini para peserta workshop mulai menyusun draft RPP, bahan ajar dan media pembelajaran yang berbasis potensi lingkungan.

Pada Tahap 4, setiap kelompok mempresntasikan hasil diskusi mereka berupa 
draf awal rancangan pembelajaran berbasis potensi lingkungan (Gambar 2). Kelompok lain memberikan saran, ide atau kontribusi terhadap rancangan awal tersebut. Instruktur tim pengabdian juga memberikan masukan agar diperoleh rancangan yang lebih baik, yang menarik, melibatkan siswa secara aktif dan kreatif dengan memanfaatkan potensi yang ada di lingkungan siswa. Selanjutnya setiap kelompok peserta workshop diberi kesempatan di beberapa akhir minggu untuk menyusun rancangan pembelajaran berupa RPP, dan media pembelajaran sesuai saran dari instruktur tim pengabdian.

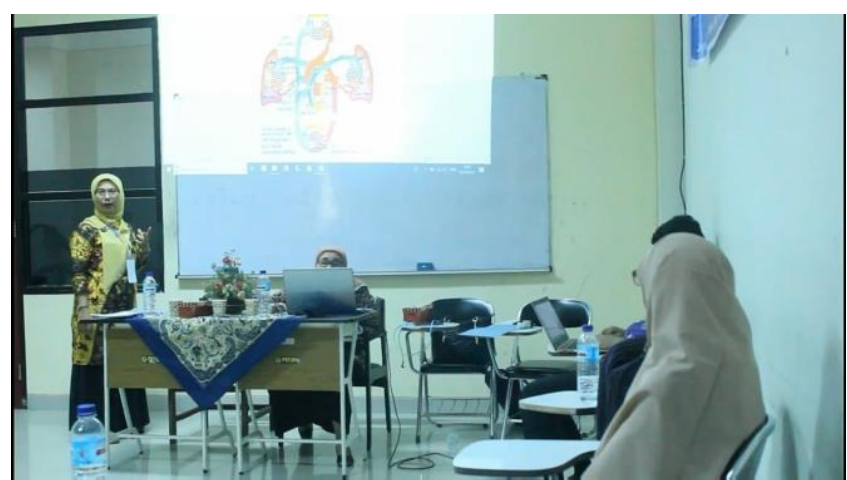

Gambar 2. Salah satu guru mempresentasikan draft hasil rancangan pembelajaran (RPP dan media pembelajaran).

Tahap 5 adalah implementasi hasil rancangan pembelajaran setiap kelompok. Sesuai kesepakatan, implementasi dilaksanakan di SMP 25 Padang, sebagai percontohan dan guru model (Gambar 3).

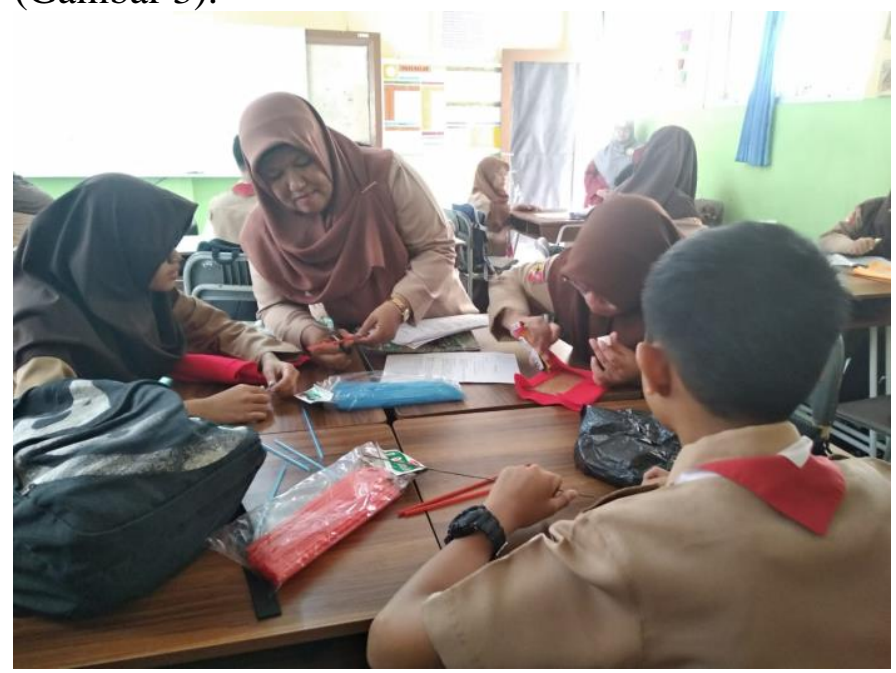

Gambar 3. Guru Model mengimplementasikan Pembelajaran Berbasis Potensi Lingkungan.
Peserta lain hadir dalam kelas sebagai observer untuk melihat keterlaksanaan rancangan pembelajaran yang telah disusun. Observer juga mengamati keaktivan, kreativitas dan keterlibatan siswa dalam menemukan konsep selama proses pembelajaran. Instruktur tim pengabdian juga bertindak sebagai observer, untuk memberikan masukan pada tahap refleksi bersama observer peserta lainnya (Gambar 4).

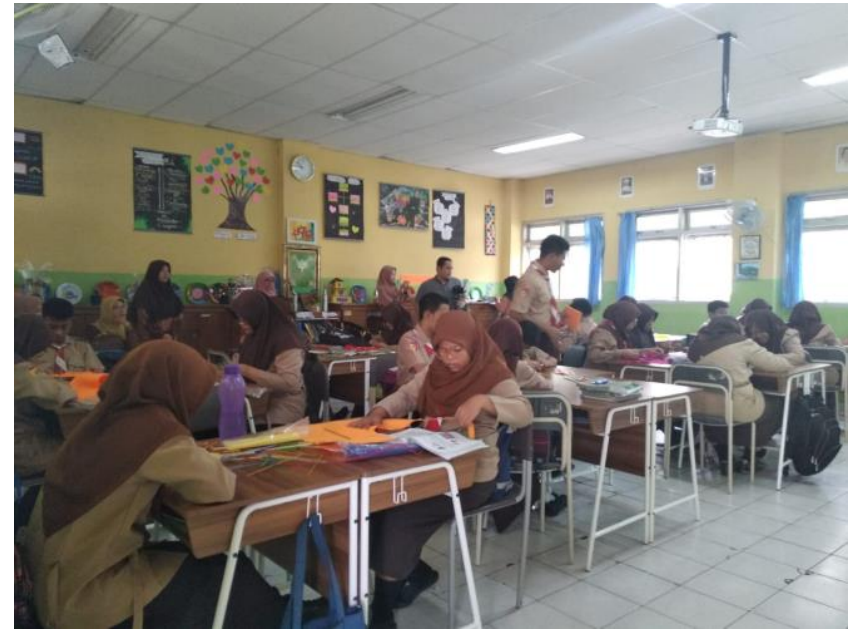

Gambar 4. Peserta workshop hadir sebagai observer di bagian belakang kelas saat implementasi.

Pada Tahap 6 dilakukan evaluasi dan refleksi (Gambar 5) yang dimulai dengan tanggapan dari guru model sendiri (self evaluation). Selanjutnya tanggapan dan masukan dari observer peserta workshop tentang ketercapaian dari implementasi. Terakhir adalah tanggapan dan masukan dari instruktur tim pengabdian. Secara umum implementasi berhasil membelajarkan siswa dengan meningkatkan aktivitas dan kreativitas siswa. 


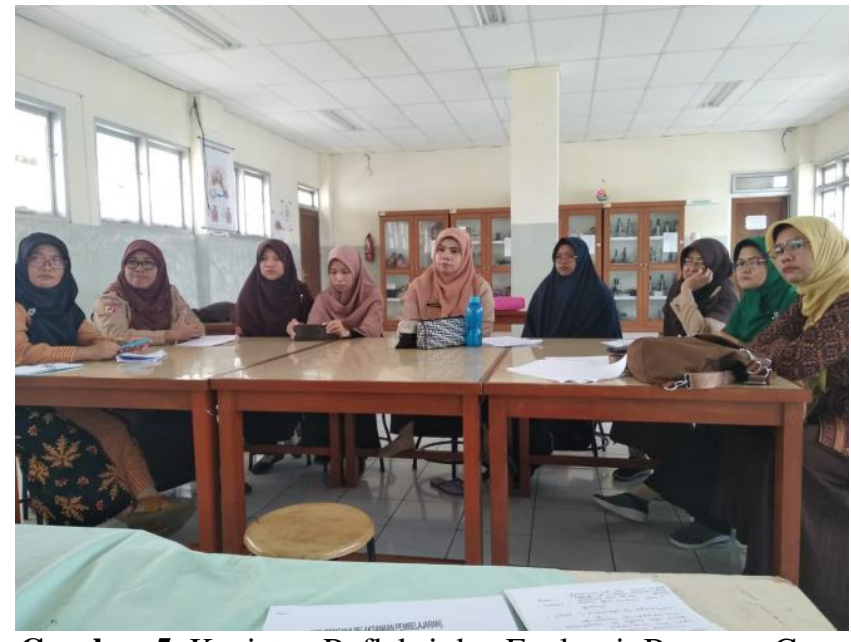

Gambar 5. Kegiatan Refleksi dan Evaluasi, Bersama Guru Model, Peserta Workshop dan Instruktur Tim Pengabdian

\section{Hasil dan Diskusi}

Kegiatan workshop berbasis masalah ini sudah terlaksana sesuai dengan tahapan yang terdapat pada perencanaan. Sudah dihasilkan 3 perangkat pembelajaran IPA SMP berbasis potensi lingkungan masing masing topik yang dirasa sulit untuk kelas 7, 8, dan 9. Tiga topik terpilih sebagai materi yang dirasa sulit bagi guru dalam merancang pembelajaran berbasis potensi lingkungan adalah materi suhu dan pemuaian (kelas 7), materi sistem peredaran darah (kelas 8), dan materi pewarisan sifat (kelas 9).

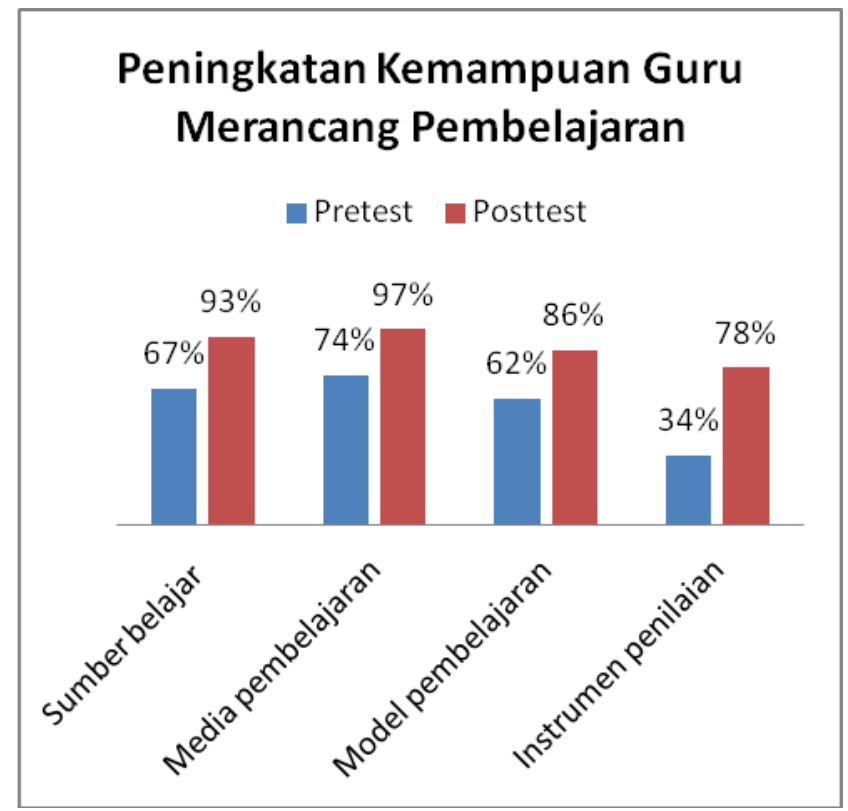

Gambar 6. Peningkatan kompetensi guru dalam merancang Pembelajaran Berbasis Potensi Lingkungan
Sudah terjadi peningkatan kompetensi guru menyusun perangkat pembelajaran, yang dapat dilihat dari pemilihan sumber belajar, media, model/ metode/ pendekatan, dan penilaian, sebagaimana dapat dilihat pada Gambar 6. Pada saat pretest, kemampuan guru menyusun instrumen penilaian yang berbasis potensi lingkungan masih sangat rendah. Hal ini karena dalam menyusun soal-soal evaluasi, guru belum mengaitkan dengan lingkungan sekitar siswa. Pada aspek pemilihan sumber belajar, media dan model/metode/ pendekatan pembelajaran, guru telah mengaitkan dengan lingkungan tetapi belum optimal dan belum menggunakan teknologi sesuai tuntutan pembelajaran abad 21. Pada kegiatan workshop ini guru dibimbing untuk merancang RPP dan video pembelajaran berbasis potensi lingkungan.

Pada tahap implementasi, berdasarkan masalah guru peserta workshop sepakat untuk memilih materi pewarisan sifat sebagai model yang diimplementasikan, karena dianggap paling sulit menemukan potensi lingkungan untuk membelajarkan siswa. Potensi ligkungan yang digunakan guru model sebagai media pembelajaran adalah foto keluarga masingmasing siswa dan video tentang pewarisan sifat pada suatu keluarga (Gambar 7). Siswa juga membawa berbagai peralatan sederhana seperti benang, kawat, pipet, kain flanel untuk membuat model struktur DNA yang mendasari pewarisan sifat (Gambar 8).

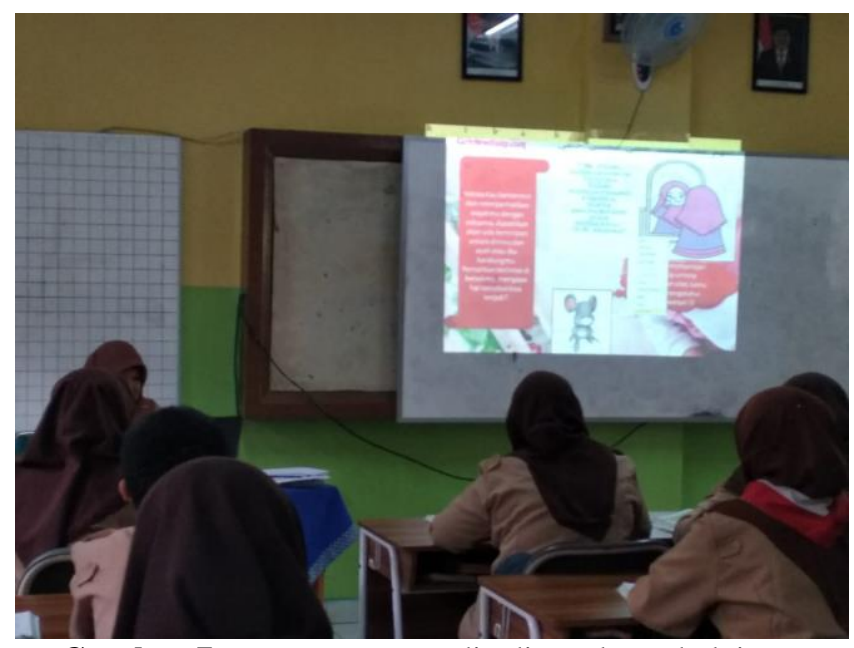

Gambar 7. Penggunaan Media di awal Pembelajaran 
Selain terjadi peningkatan kompetensi guru, kegiatan workshop juga berdampak pada peningkatan kualitas pembelajaran siswa. Siswa terlibat aktif dalam belajar atau pembelajaran yang berpusat pada siswa (student-centered learning). Siswa bekerjasama dalam kelompok membuat model sederhana dobel helix struktur DNA untuk meningkatkan pemahaman siswa tentang materi pewarisan sifat (Gambar 8).

Pembelajaran sains (IPA) yang melibatkan siswa secara aktif layaknya ilmuwan perlu dilakukan agar siswa paham konsep dan tidak terjadi miskonsepsi [4,5]. Sebagaimana karakteristik pembelajaran sains, siswa perlu berintreraksi dengan lingkungan, mencobakan sesuatu, berpikir kritis dan kreatif mengemukakan ide-idenya. Hal ini hanya mungkin dilakukan jika rancangan pembelajaran yang dibuat guru sudah diatur sedemikian rupa untuk mengaktifkan siswa, yaitu adanya kegiatan eksperimen, diskusi kelompok, diskusi kelas, dan memberi kesempatan siswa untuk presentasi. Dan hal yang lebih penting adalah para guru harus punya komitemen untuk melaksanakan rancangan (RPP) tersebut dengan maksimal, tidak hanya sebagai pelengkap administratif yang diwajibkan ada sebelum proses pembelajaran. Pada kegiatan workshop, rancangan pembelajaran yang telah disusun, diimplementasikan oleh guru model.

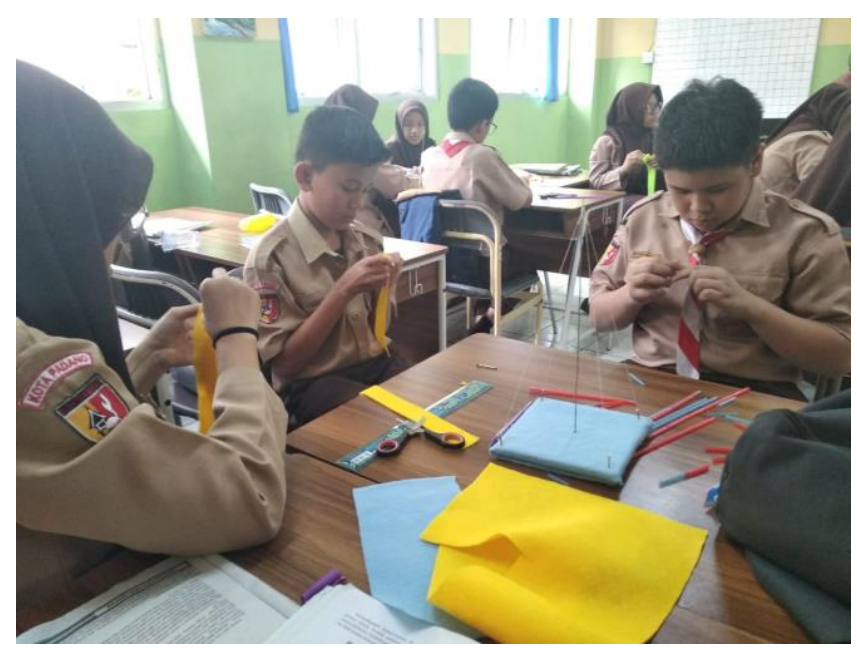

Gambar 8. Siswa terlibat aktif dalam pembelajaran: merancang struktur DNA sebagai dasar pewarisan sifat.

Pembelajaran oleh guru model telah mengasah keterampilan 4C yang dituntut pada pembelajaran abad 21, yaitu creativity (kreativitas), collaboration (kerjasama), critical thinking (berpikir kritis) dan communication (berkomunikasi) pada saat diskusi dan bekerja dalam kelompok. Demikian juga pada saat siswa presentasi dan diskusi kelas (Gambar 9), telah memberi kesempatan dan melatih siswa berkomunikasi dan mengemukakan pendapat. Hal ini juga disampaikan menteri pendidikan dan kebudayaan pada hari guru agar memberikan kesempatan kepada siswa untuk mengajar di depan kelas [6]. Selain itu pendidikan dan peningkatan potensi diri perlu dilakukan untuk menyikapi era globalisasi atau revolusi industri 4.0 khususnya kemampuan komunikasi, kolaborasi, berpikir kritis, kreatif dan inovatif [7].

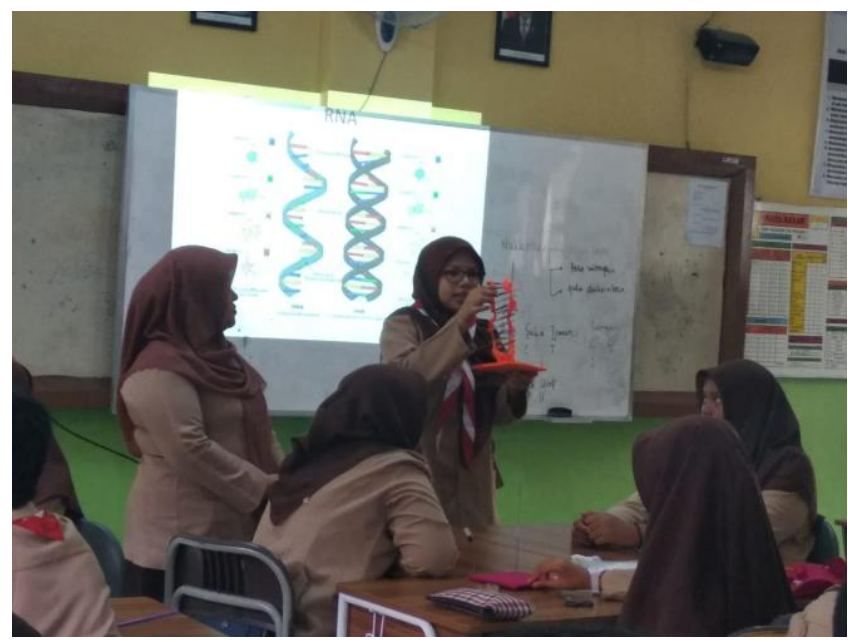

Gambar 9. Salah satu siswa mempresentasikan hasil kerja kelompok, manjelaskan tentang konsep struktur DNA

Pada tahap refleksi, para guru peserta workshop yang pertindak sebagai observer saat implementasi mengungkapkan bahwa guru model telah berhasil melaksanakan pembelajaran sesuai rancangan/RPP berbasis potensi lingkungan yang telah disusun. Guru model juga berhasil menjadi contoh dalam mengaktifkan siswa belajar, melibatkan dan melatih kreativitas siswa. Walaupun siswa masih belum terbiasa mengemukakan ide atau mengeluarkan pendapat (komunikasi), namun rancangan pembelajaran yang telah disusun dapat melatih siswa untuk membiasakan keterampilan 4C sesuai tuntutan pembelajaran abad 21.

Workshop berbasis masalah telah berhasil melatih guru dalam merancang pembelajaran berbasis potensil lingkugan dan juga berhasil meningkatkan kualitas belajar siswa. Melalui 
workshop berbasis masalah, terjadi interaksi yang baik antar guru dalam mengungkapkan masalah utama mereka dan mencarikan solusi yang tepat. Temuan ini juga sesuai dengan penelitian [8] yang menemukan bahwa aktivitas workshop berbasis PBL, memfasilitasi peserta workshop untuk berinteraksi dan bekerjasama dengan baik. Aktivitas diskusi kelompok, kerja kelompok, presentasi, dan revisi berdampak positif terhadap kerjasama antar peserta workshop dalam menyelesaikan permasalahan autentik mereka, terutama dalam merancang pembelajaran yang berbasis potensi lingkungan. Keberhasilan workshop ini sesuai dengan penelitian yang menemukan bahwa bahan ajar yang dihasilkan dari workshop berbasis PBL lebih bagus dari bahan ajar yang disusun guru pada workshop dengan pendekatan konvensional [8].

\section{Kesimpulan}

Berdasarkan kegiatan yang dilakukan, maka diperoleh kesimpulan, yaitu: workshop berbasis masalah berhasil meningkatkan kompetensi guru dalam merancang perangkat pembelajaran IPA SMP berbasis potensi lingkungan. Hasil implementasi produk workshop menunjukan pengaruh positif terhadap keberhasilan guru dalam melibatkan siswa aktif dalam pembelajaran (student-centered learning) serta melatih keterampilan 4C (creativity \& inovation, collaboration, critical thingking and communication) sesuai tuntutan pembelajaran abad 21.

\section{Ucapan Terima Kasih}

Ucapan terima kasih Rektor UNP yang telah mendanai kegiatan pengabdian ini melalui skema Pengabdian Kemitraan Masyarakat (PKM) pendanaan tahun 2019. Terima kasih juga diucapkan kepada Bapak Taufik Hendra, S.Pd, selaku Ketua MGMP IPA SMP Kota Padang, atas kerjasamanya sehingga pengabdian ini dapat terlaksana dengan baik. Terima kasih kepada Kepala Sekolah SMP 25 Padang yang telah memfasilitasi kegiatan implementasi dan kepada Ibu Netti Esmar, S.Pd, guru SMP 25 Padang yang bersedia sebagai guru model. Kegiatan ini juga melibatkan mahasiswa S1 jurusan fisika: Iftitah Khairunnisa, Putri Rasti Rahmadhani dan Riska Okta Perrina yang membantu dalam hal teknis.

\section{Pustaka}

[1] Ronis, D. (2001). Problem-Based Learning for Math and Science: Integrating Inquiry and the Internet. United States of America: A Pearson Education Company, Skylight Training and Publishing, Inc

[2] Suhanji, Konsep Pendidikan Orang Dewasa, 2013, Jurnal Kependidikan, Vol. 1 No. 1 Nopember 2013. http://ejournal.iainpurwokerto.ac.id/index.php/i urnalkependidikan/article/view/528

[3] Houde, Josep, 2006, Andragogy and Motivation: An Examination of the Principles of Andragogy through Two Motivation Theories, Copyright (C) 2006 Joseph Houde.,AHRD ConProceedings.doc. https://eric.ed.gov/?id=ED492652

[4] Mufit, F. (2016). A Study about Understanding the Concept of Force and Attitude towards Learning Physics on First-Year Students in the Course of General Physics; as Preliminary Investigation in Development Research. https://doi.org/10.31227/osf.io/8n6ep

[5] F Mufit et al 2019 J. Phys.: Conf. Ser. 1317 012156

https://iopscience.iop.org/article/10.1088/17426596/1317/1/012156/meta

[6] https://www.kemdikbud.go.id/main/blog/2019/11/ pidato-mendikbud-pada-upacara-benderaperingatan-hari-guru-nasional-tahun-2019

[7] Suwardana, H. (2017). Revolusi Industri 4. 0 Berbasis Revolusi Mental. Jati Unik, Vol. 1, No. 2, 102-110.

http://ojs.unik-

kediri.ac.id/index.php/jatiunik/article/download/1 $17 / 87$

[8] Desnita, Raihanati, Muhamad Adrian Leonda, 2014, Strategi Workshop Penyusunan Bahan Ajar Fisika Berbasis Problem Based Learning Bagi Guru SMA/MA. http://journal.unj.ac.id/uni/index.php/prosidings nf/article/view/5504 